\section{Loyalitas Kreativitas \\ Aldi Masyarakat Kreatif}

P-ISSN 2722-2101, E-ISSN 2722-4201

Program Studi Ekonomi Manajemen Universitas Pamulang

Jurnal LOKABMAS Kreatif Vol.02,No.03.Nov 2021 Hal.31-38

Email:jurnalkreatif.manajemen@gmail.com

\title{
SOSIALISASI PENCEGAHAN PENULARAN VIRUS COVID-19 PADA KELURAHAN CIPUTAT, CIPUTAT TANGERANG SELATAN
}

\author{
Shella Puspita Sari ${ }^{1}$, Ayu Puspa Lestiyadi ${ }^{2}$, Kartika Sari Dewi ${ }^{3}$, Tutri Indraswari ${ }^{4}$ \\ Dosen ManajemenFakultas Ekonomi Universitas Pamulang \\ Email: dosen02512@unpam.ac.id, ayupuspalestiyadi@yahoo.co.id, \\ kartikascorpio@yahoo.co.id, dosen02446@unpam.ac.id
}

\begin{abstract}
ABSTRAK
Kegiatan Pengabdian Kepada Masyarakat ini bertujuan untuk memberikan sosialisasi pencegahan penularan virus Covid-19 terhadap pada staff ataupun peserta. Metode kegiatan yang digunakan adalah kerjasama dengan Bapak Lurah Kelurahan Ciputat, yang beralamat di Ciputat, Tangerang Selatan dan memberikan sosialisasi serta pengarahan cara mengantisipasi penularan virus Covid19 pada masyarakat. Setelah di analisis maka kami memberikan sosialisasi dan pemaparan virus Covid-19 dari mulai gejala yang timbul di lingkungan keluarga dan masyarakat, cara penyembuhan hingga bagaimana menghadapi orang yang sedang mengidap Covid-19. Hasil kegiatan menunjukkan bahwa sebelum pelaksanaan PKM, para staff Kelurahan Ciputat belum mengetahui hal apa saja yang bisa dilakukan untuk meningkatkan pengetahuan tentang penularan virus Covid-19, namun setelah pelaksanaan kegiatan PKM ini diketahui para peserta setidaknya sudah mempunyai sedikit bekal dan dapat memahami virus Covid-19, dan bagaimana cara mengantisipasi penularan virus Covid-19, mengetahui apa saja gejala Covid-19, dan bagaimana cara penyembuhannya. Kegiatan PKM berperan positif dalam meningkatkan pengetahuan dan pengharapan untuk selalu meningkatkan kebersihan dan jaga kesehatan.
\end{abstract}

Kata Kunci : PKM, Sosialisasi, Pencegahan, Penularan, Virus Covid-19

This Community Service activity aims to provide socialization of the prevention of the transmission of the Covid-19 virus to staff and participants. The method of activity used is in collaboration with the Village Head of Ciputat Village, whose address is in Ciputat, South Tangerang and provides socialization and guidance on how to anticipate the transmission of the Covid-19 virus to the community. After the analysis, we provide socialization and exposure to the Covid-19 virus from the symptoms that arise in the family and community, ways of healing to how to deal with people who are suffering from Covid-19. The results of the activity showed that prior to the implementation of the PKM, the Ciputat Sub-district staff did not know what things could be done to increase knowledge about the transmission of the Covid-19 virus, but after the implementation of this PKM activity it was known that the participants at least had the provisions and could understand the Covid-19 virus. , and how to anticipate the transmission of the Covid-19 virus, find out what the symptoms of Covid-19 are, and how to cure it. PKM activities play a positive role in increasing appreciation and to always improve health care and maintenance.

Keywords: PKM, Socialization, Prevention, Transmission, Covid-19 Virus

\section{PENDAHULUAN}

Virus Corona merupakan keluarga besar virus yang menyebabkan penyakit pada manusia dan hewan. Pada manusia biasanya menyebabkan penyakit infeksi saluran pernapasan, mulai flu biasa hingga penyakit yang serius seperti Middle East Respiratory Syndrome (MERS) dan
Sindrom Pernafasan Akut Berat/ Severe Acute Respiratory Syndrome (SARS). Coronavirus jenis baru yang ditemukan pada manusia sejak kejadian luar biasa muncul di Wuhan Cina, pada Desember 2019, kemudian diberi nama Severe Acute Respiratory Syndrome Coronavirus 2 (SARS-COV2), dan menyebabkan 


\section{Loyalitas Kreativitas Aldi Masyarakat Kreatif}

P-ISSN 2722-2101, E-ISSN 2722-4201

Program Studi Ekonomi Manajemen Universitas Pamulang

Jurnal LOKABMAS Kreatif Vol.02,No.03.Nov 2021 Hal.31-38

Email:jurnalkreatif.manajemen@gmail.com penyakit Coronavirus Disease-2019 (COVID-19).

Orang yang tinggal atau bepergian di daerah di mana virus COVID-19 bersirkulasi sangat mungkin berisiko terinfeksi. Mereka yang terinfeksi adalah orang-orang yang dalam 14 hari sebelum muncul gejala melakukan perjalanan dari negara terjangkit, atau yang kontak erat, seperti anggota keluarga, rekan kerja atau tenaga medis yang merawat pasien sebelum mereka tahu pasien tersebut terinfeksi COVID-19.

Petugas kesehatan yang merawat pasien yang terinfeksi COVID-19 berisiko lebih tinggi dan harus konsisten melindungi diri mereka sendiri dengan prosedur pencegahan dan pengendalian infeksi yang tepat.

Orang yang terinfeksi COVID-19 dan influenza akan mengalami gejala infeksi saluran pernafasan yang sama, seperti demam, batuk dan pilek. Walaupun gejalanya sama, tapi penyebab virusnya berbeda-beda, sehingga kita sulit mengidentifikasi masing-masing penyakit tersebut. Pemeriksaan medis yang akurat disertai rujukan pemeriksaan laboratorium sangat diperlukan untuk mengonfirmasi apakah seseorang terinfeksi COVID-19. Bagi setiap orang yang menderita demam, batuk, dan sulit bernapas sangat direkomendasikan untuk segera mencari pengobatan, dan memberitahukan petugas kesehatan jika mereka telah melakukan perjalanan dari wilayah terjangkit dalam 14 hari sebelum muncul gejala, atau jika mereka telah melakukan kontak erat dengan seseorang yang sedang menderita gejala infeksi saluran pernafasan.

Tidak ada batasan usia orang-orang dapat terinfeksi oleh coronavirus ini (COVID-19). Namun orang yang lebih tua, dan orang-orang dengan kondisi medis yang sudah ada sebelumnya (seperti asma, diabetes, penyakit jantung, atau tekanan darah tinggi) tampaknya lebih rentan untuk menderita sakit parah maka dari itu masyarakat diwajibkan melakukan vaksin guna mengurangi pencegahan lebih lanjut, di dalam Peraturan Menteri Kesehatan Nomor 18 Tahun 2021 tentang Perubahan atas Peraturan Menteri Kesehatan Nomor 10 Tahun 2021 tentang Pelaksanaan Vaksinasi dalam rangka Penanggulangan Pandemi Corona Virus Disease 2019 (COVID-19) (Berita Negara Republik Indonesia Tahun 2021 Nomor 592) dalam peraturan Menteri pasal 1 di sebutkan bahwa "Vaksin adalah produk biologi yang berisi antigen berupa mikroorganisme yang sudah mati atau masih hidup yang dilemahkan, masih utuh atau bagiannya, atau berupa toksin mikroorganisme yang telah diolah menjadi toksoid atau protein rekombinan, yang ditambahkan dengan zat lainnya, yang bila diberikan kepada seseorang akan menimbulkan kekebalan spesifik secara aktif terhadap penyakit tertentu".

Vaksinasi adalah pemberian Vaksin yang khusus diberikan dalam rangka menimbulkan atau meningkatkan kekebalan seseorang secara aktif terhadap suatu penyakit, sehingga apabila suatu saat terpajan dengan penyakit tersebut tidak akan sakit atau hanya mengalami sakit ringan dan tidak menjadi sumber penularan. Vaksinasi Gotong Royong adalah pelaksanaan vaksinasi COVID 19 kepada individu/orang perorangan yang pendanaannya dibebankan kepada yang bersangkutan, atau pelaksanaan vaksinasi COVID-19 kepada karyawan/karyawati, keluarga atau individu lain terkait dalam keluarga yang pendanaannya ditanggung atau dibebankan pada badan hukum/badan usaha.

Gambaran tentang bagaimana memberikan sosialisasi tentang pencegahan Covid-19 dan dari sistem rumah tangga terpengaruh oleh pandemi jauh lebih kompleks dari yang dibayangkan, satu hal yang pasti adalah bagaimana bentuknya hari ini akan memiliki efek jangka panjang di tengah masyarakat. Menyingkapi hal tersebut, baiknya setiap pelaku rumah tangga sigap dan memiliki pengetahuan dasar untuk 


\section{Loyalitas Kreativitas \\ Aldi Masyarakat Kreatif}

P-ISSN 2722-2101, E-ISSN 2722-4201

Program Studi Ekonomi Manajemen Universitas Pamulang

Jurnal LOKABMAS Kreatif Vol.02,No.03.Nov 2021 Hal.31-38

Email:jurnalkreatif.manajemen@gmail.com membantu mencegah penularan virus covid-19 dari keluarganya dan dari segala aspek yang berdampak dimasa pandemi seperti sekarang ini.

Berdasarkan fenomena tersebut, kami para Dosen Universitas Pamulang dari Prodi Manajemen dan mahasiswa mengadakan Pengabdian Kepada Masyarakat (PKM) bersama dengan para staff kelurahan Ciputat, Ciputat, Tangerang Selatan untuk memberikan pengarahan terkait sosial media dengan tema "Sosialisasi Pencegahan Penularan Virus Covid-19 pada staff di Kelurahan Ciputat, Ciputat, Tangerang Selatan".

\section{RUMUSAN MASALAH}

Berdasarkan latar belakang tersebut, berikut rumusan masalah pengabdian kepada masyarakat di Kelurahan Ciputat :

1. Bagaimana memberikan pemahaman cara pencegahan virus Covid-19?

2. Melihat sejauh mana Kelurahan Ciputat sudah mensosialisasikan kepada lingkungan sekitar cara mencegah virus corona?

3. Bagaimana memberikan pemahaman tentang memperlakukan masyarakat yang terpapar Covid-19 di tengah masa pandemi saat ini kepada Staff Kelurahan Ciputat?

4. Bagaimana memberikan solusi-solusi alternatif sebagai penghasilan tambahan di tengah masa pandemi saat ini kepada Staff Kelurahan Ciputat?

\section{TUJUAN PELAKSANAAN}

1. Tujuan Umum

Yaitu mensosialisasikan bagaimana cara pencegahan dan penularan Virus Covid-19 pada Kelurahan Ciputat.

2. Tujuan Khusus
a) Melaksanakan protokol pencegahan Virus Covid-19 di lingkungan Kelurahan Ciputat.
b) Melaksanakan langkah-langkah kewaspadaan dan pencegahan penyebaran virus Covid-19 di lingkungan Kelurahan Ciputat.

c) Melaksanakan Komunikasi risiko dan pemberdayaan masyarakat dalam bentuk peran serta kepedulian kepada masyarakat berdampak Covid-19.

\section{TINJAUAN PUSTAKA}

\section{Pengertian Virus Corona}

Infeksi virus Corona disebut COVID (Corona Virus Disease 2019) dan pertama kali ditemukan di kota Wuhan, China pada akhir Desember 2019. Virus ini menular dengan sangat cepat dan telah menyebar ke hampir semua negara, termasuk Indonesia, hanya dalam waktu beberapa bulan. Hal tersebut membuat beberapa negara menerapkan kebijakan untuk memberlakukan lockdown_dalam rangka mencegah penyebaran virus Corona. Di Indonesia sendiri, diberlakukan kebijakan Pembatasan Sosial Berskala Besar (PSBB) untuk menekan penyebaran virus ini.

Corona virus adalah kumpulan virus yang bisa menginfeksi sistem pernapasan. Pada banyak kasus, virus ini hanya menyebabkan infeksi pernapasan ringan, seperti flu. Namun, virus ini juga bisa menyebabkan infeksi pernapasan berat, seperti infeksi paru-paru (pneumonia).

Virus ini menular melalui percikan dahak (droplet) dari saluran pernapasan, misalnya ketika berada di ruang tertutup yang ramai dengan sirkulasi udara yang kurang baik atau kontak langsung dengan droplet. Selain virus SARS-CoV-2 atau virus Corona, virus yang juga termasuk dalam kelompok ini adalah virus penyebab Severe Acute Respiratory Syndrome (SARS) dan virus penyebab Middle-East Respiratory Syndrome (MERS). Meski disebabkan oleh virus dari kelompok yang sama, yaitu coronavirus, COVID-19 memiliki beberapa perbedaan dengan SARS dan MERS, antara lain dalam hal kecepatan penyebaran dan keparahan gejala. 


\section{Loyalitas Kreativitas Aldi Masyarakat Kreatif}

P-ISSN 2722-2101, E-ISSN 2722-4201

Program Studi Ekonomi Manajemen Universitas Pamulang

Jurnal LOKABMAS Kreatif Vol.02,No.03.Nov 2021 Hal.31-38

Email:jurnalkreatif.manajemen@gmail.com
Menurut ahli virus atau virologis Richard Sutejo, virus corona penyebab sakit Covid-19 merupakan tipe virus yang umum menyerang saluran pernafasan. Tetapi strain covid-19 memiliki morbiditas dan mortalitas yang lebih tinggi akibat adanya mutasi genetik dan kemungkinan transmisi inter-spesies.

"Virus ini, seperti halnya pendahulunya, MERS dan SARS, mematikan karena menyerang paru-paru dan menimbulkan Acute Respiratory Distress Syndrome yang membahayakan nyawa penderita sehingga memerlukan ventilator untuk bertahan hidup," kata Richard yang juga Head of Master in Bio Management i3L dalam keterangan resmi yang diterima Suara.com.

Richard menambahkan selain menerapkan Pembatasan Sosial Skala Besar (PSSB), salah satu cara efektif untuk menekan penyebaran Covid-19 adalah dengan melakukan tes massal.

\section{Gejala Virus corona}

Virus Corona atau severe acute respiratory syndrome coronavirus 2 (SARS-CoV-2) adalah virus yang menyerang sistem pernapasan. Penyakit karena infeksi virus ini disebut COVID19. Virus Corona bisa menyebabkan gangguan ringan pada sistem pernapasan, infeksi paru-paru yang berat, hingga kematian. Gejala umum berupa demam $\geq 380 \mathrm{C}$, batuk kering, dan sesak napas. Jika ada orang yang dalam 14 hari sebelum muncul gejala tersebut pernah melakukan perjalanan ke negara terjangkit, atau pernah merawat/kontak erat dengan penderita COVID-19, maka terhadap orang tersebut akan dilakukan pemeriksaan laboratorium lebih lanjut untuk memastikan diagnosisnya. Gejala Virus Corona (COVID-19).

\section{Penyebab Virus Corona (OVID-19)}

Infeksi virus Corona atau COVID-19 disebabkan oleh coronavirus, yaitu kelompok virus yang menginfeksi sistem pernapasan. Pada sebagian besar kasus, coronavirus hanya menyebabkan infeksi pernapasan ringan sampai sedang, seperti flu. Akan tetapi, virus ini juga bisa menyebabkan infeksi pernapasan berat, seperti pneumonia, Middle-East Respiratory Syndrome (MERS) dan Severe Acute Respiratory Syndrome (SARS). Ada dugaan bahwa virus Corona awalnya ditularkan dari hewan ke manusia. Namun, kemudian diketahui bahwa virus Corona juga menular dari manusia ke manusia.

Seseorang dapat tertular COVID-19 melalui berbagai cara, yaitu:

- Tidak sengaja menghirup percikan ludah (droplet) yang keluar saat penderita COVID-19 batuk atau bersin

- Memegang mulut atau hidung tanpa mencuci tangan terlebih dulu setelah menyentuh benda yang terkena cipratan ludah penderita COVID-19

- Kontak jarak dekat dengan penderita COVID-19

Virus Corona dapat menginfeksi siapa saja, tetapi efeknya akan lebih berbahaya atau bahkan fatal bila terjadi pada orang lanjut usia, ibu hamil, orang yang memiliki penyakit tertentu, perokok, atau orang yang daya tahan tubuhnya lemah, misalnya pada penderita kanker. Karena mudah menular, virus Corona juga berisiko tinggi menginfeksi para tenaga medis yang merawat pasien COVID-19. Oleh karena itu, para tenaga medis dan orang-orang yang memiliki kontak dengan pasien COVID-19 perlu menggunakan alat pelindung diri (APD).

\section{METODE PELAKSANAAN}

Metode kegiatan ini berupa sosialisasi pencaegahan Virus Covid-19 di Kelurahan Ciputat,berikut ini adalah tahapan pelatihan yang dilakukan:

1. Tahap Persiapan

Tahap persiapan yang dilakukan meliputi: 


\section{Loyalitas Kreativitas Aldi Masyarakat Kreatif}

P-ISSN 2722-2101, E-ISSN 2722-4201

Program Studi Ekonomi Manajemen Universitas Pamulang

Jurnal LOKABMAS Kreatif Vol.02,No.03.Nov 2021 Hal.31-38

Email:jurnalkreatif.manajemen@gmail.com a. Survey awal, pada tahap ini dilakukan survei ke lokasi Kantor Kelurahan Ciputat di Jl. Ki Hajar Dewantara No. 7

b. Pemantapan dan penentuan lokasi dan sasaran. Setelah survey maka ditentukan lokasi pelaksanaan dan sasaran peserta kegiatan.

c. Penyusunan bahan/materi sosialisasi penggunaan aplikasi e-litigation.

2. Tahap Pelaksanaan Penelitian

Tahap ini akan diberikan penjelasan mengenai cara pencegahan virus corona

3. Tahap Penyuluhan

Untuk melaksanakan kegiatan tersebut digunakan beberapa metode penyuluhan yaitu:

a. Metode Ceramah

Metode ceramah dipilih untuk memberikan penjelasan tentang pentingnya mendaftarkan akun elitigation dalam penyelesaian perkara di Persidangan.

b. Metode Tanya Jawab

Metode Tanya jawab sangat penting bagi para peserta pelatihan. Metode ini memungkinkan para peserta menggali pengetahuan sebanyakbanyaknya tentang cara pencegahan virus corona

c. Metode Simulasi

Metode simulasi ini diberikan kepada para peserta penyuluhan dengan memberikan contoh cara mencuci tangan yang baik, menggunakan handsanitizer setelah melakukan aktivitas atau memegang suatu barang.

\section{HASIL DAN PEMBAHASAN}

Setelah dilaksanakan pengarahan sosialisasi pencegahan penularan virus Covid19, maka tingkat keberhasilan penyelenggaraan kegiatan Pengabdian Kepada Masyarakat ini dapat dilihat dari hasil evaluasi selama pelaksanaan kegiatan, yaitu:

1. Evaluasi proses yaitu untuk mengetahui pelaksanaan dari program yang dibuat serta keterlibatan peserta atau khalayak sasaran antara strategis selama mengikuti kegiatan.
Evaluasi ini dilakukan dari awal sampai akhir kegiatan dengan melihat tanggapan peserta penjelasan dan contoh-contoh yang diberikan, melakukan sesi tanya jawab yang interkatif namun hanya ada beberapa staff atau peserta yang belum bisa menangkap materi dengan baik dikarenakan usia.

2. Evaluasi hasil yaitu untuk mengetahui seberapa jauh tingkat keberhasilan tujuan yang telah dirumuskan, dapat dilihat dari respon (tanggapan) peserta terhadap sosialisasi pelatihan yang telah dilakukan pada saat kegiatan berlangsung.

Sosialisasi dilakukan selama dua hari pada tanggal 22 s/d 23 Maret 2021 dihadiri perserta di Kantor kelurahan sebanyak 25 peserta. Semua peserta mengikuti kegiatan secara penuh dikarenakan semua peserta antusias mengikuti kegiatan pengarahan dan pengimplentasian. Dari respon (tanggapan peserta) yang diberikan meraka semua sangat berharap kegiatan Pengabdian Kepada Masyarakat seperti ini dalam dilakukan kembali pada periode-periode berikutnya. Adapun beberapa faktor pendorong terlaksananya kegiatan sosialisasi ini adalah sebagai berikut:

1. Dari pihak peserta (para staff kelurahan) begitu antusias dalam mengikuti seluruh rangkaian kegiatan pengabdian pada masyarakat ini.

2. Pelaksanaan kegiatan ini dapat memberikan pengetahuan tambahan/menambah wawasan bagi peserta mengenai pencegahan penularan virus Covid-19.

3. Kesiapan dan semangat para peserta kegiatan ini begitu besar untuk mendapatkan pengetahuan yang disiapkan oleh panitia pelaksana.

4. Faktor pendorong lainnya adalah kesiapan anggota tim pelaksana yang telah menyiapkan diri, terutama dalam pemberi materi pada kegiatan pengabdian ini sangatlah interaktif dan memberikan suasana yang bersahaja.

\section{KESIMPULAN DAN SARAN KESIMPULAN}

Pelaksanaan kegiatan pengabdian kepada masyarakat oleh Lembaga 


\section{Loyalitas Kreativitas \\ Aldi Masyarakat Kreatif}

P-ISSN 2722-2101, E-ISSN 2722-4201

Program Studi Ekonomi Manajemen Universitas Pamulang

Jurnal LOKABMAS Kreatif Vol.02,No.03.Nov 2021 Hal.31-38

Email:jurnalkreatif.manajemen@gmail.com
Penelitian dan Pengabdian Masyarakat (LPPM) Universitas Pamulang yang dilakukan oleh dosen-dosen Universitas pada program studi manajemen telah berjalan dengan lancar dan mendapat sambutan hangat dari tempat pelaksanaan kegiatan ini yaitu Kantor Kelurahan Ciputat, Ciputat, Tangerang Selatan.

Harapan kami selaku dosen, dengan pengabdian ini dapat menambah pemahaman dan wawasan tentang bagaimana menghadapi virus corona-19 yang perlu dilakukan guna meningkatkan kesehatan dari diri sendiri, keluarga maupun masyarakat bagi masing-masing rumah tangga.

Materi yang kami berikan yaitu tentang gambaran secara umum covid-19 dan memberikan sosialisasi ke masyarakat bagaimana cara pencegahan penularan virus covid-19, bagaimana cara menghadapi nya jika ada yang terpapar virus covid-19 dan yang perlu dilakukan guna meningkatkan pemahaman para peserta dan membangkitkan keinginan untuk hidup bersih dan menjaga protokol kesehatan dan dapat mengimplementasikan ilmu yang di dapat dalam sosialisasi ini dalam kehidupan sehari-hari, sehingga dapat membantu dan meningkatkan taraf ekonomi rumah tangga yang sehat dan bermanfaat dalam kehidupan mereka pada masa yang akan datang.

\section{SARAN}

Dalam laporan kegiatan ini mungkin banyak kekurangan yang ada, untuk itu kami

berharap masukan dan kritikan dalam rangka perbaikan untuk kegiatan-kegiatan pengabdian masyarakat di masa yang akan datang. Semoga kegiatan pengabdian masyarakat ini dapat bermanfaat bagi masyarakat sekitar Universitas Pamulang.

Akhirnya, kami mengucapkan terima kasih kepada seluruh pihak yang telah mendukung kegiatan yang kami laksanakan dan kami mohon maaf apabila dalam laporan ini banyak ditemukan kekurangan.

\section{DAFTAR PUSTAKA.}

Elburdah, R. P., Pasaribu, V. L. D., Rahayu, S., Septiani, F., \& Metarini, R. R. A. (2021). MOMPRENEUR PENOPANG PEREKONOMIAN KELUARGA DI MASA PANDEMI COVID-19 DENGAN BISNIS ONLINE PADA KELURAHAN PONDOK BENDA. Abdi Laksana: Jurnal Pengabdian Kepada Masyarakat, 2(1), 75-82

Pasaribu, V. L. D., Agrasadya, A., Shabrina, N., \& Krisnaldy, K. (2020). Menjadi Enterpreneur Muda Yang Memiliki Jiwa Leadership Untuk Menghadapi Masa Depan. Abdi Laksana: Jurnal Pengabdian Kepada Masyarakat, 1(1).

Pasaribu, V. L. D., Susanti, F., \& Hartuti, E. T. K. (2019). Memotivasi Siswa dan Siswi SMK Letris Indonesia di Dalam Menentukan Pilihan Untuk Melanjutkan Pendidikan Atau Bekerja Setelah Lulus Sekolah. Jurnal Pengabdian Dharma Laksana, 1(2), 161-172.

Pasaribu, V. L. D., Sulaiman, S., Sutiman, S., Thaharudin, T., \& Purnomo, B. Y. (2020). Pengenalan Letak Posyandu Terdekat Dikelurahan Pisangan Dengan Manajemen Pemasaran Revolusi 4.0 Untuk Meningkatkan Pengetahuan Masyarakat Letak Dan Fungsi Posyandu Terdekat Pada Kelurahan Pisangan. Dedikasi Pkm, l(1), 105-110.

Pasaribu, V. L. D., Oktrima, B., Prabowo, B., Arianto, N., \& Haryoko, U. B. (2020). Progam Pendampingan Dan Penyelenggaraan Pendidikan Anak Pada Usia Dini Terhadap Prestasi Belajar Dilingkungan Rt 020 Rw 009. Kel Giri Peni. Kec Wates. Yogyakarta. Jurnal Lokabmas Kreatif, 1(1), 71-75.

Pasaribu, V. L. D., Jannah, M., Fazar, M., Putra, S. P., Monalisa, M., \& Sofa, M. (2021). MENINGKATKAN PRODUKTIVITAS USAHA DIMASA PANDEMI PADA IBU PKK RT 004/003 KELURAHAN SAWAH BARU CIPUTAT, 


\section{Loyalitas Kreativitas Aldi Masyarakat Kreatif}

P-ISSN 2722-2101, E-ISSN 2722-4201

Program Studi Ekonomi Manajemen Universitas Pamulang Jurnal LOKABMAS Kreatif Vol.02,No.03.Nov 2021 Hal.31-38

Email:jurnalkreatif.manajemen@gmail.com
TANGERANG

SELATAN. Abdi

Laksana: Jurnal Pengabdian Kepada Masyarakat, 2(2), 295-301.

Pasaribu, V. L. D., Yuniati, H. L., Pranata, R., Sembayu, R., Purba, S. M., \& Nurbayani, T. T. A. (2021). MANAJEMEN KEUANGAN UNTUK MENGHADAPI DAN BERTAHAN DI ERA COVID 19. Jurnal Abdimas Tri Dharma Manajemen, 2(2), 12-18.

Pasaribu, V. L. D., Dwiyatni, A., Sabina, C., Ridwan, M., Gunawan, D. D., \& Noviani, B. C. (2021). EVALUASI PENERAPAN 3M DIMASA PANDEMIC COVID 19. Jurnal Abdimas Tri Dharma Manajemen, 2(2), 54-60.

Pasaribu, V. L. D., Syafei, A. N., Farhan, A., Aufaizah, A., Irani, C., \& Firtiayani, S. R. (2021). PENGARUH DISPLIN PROTOKOL KESEHATAN TERHADAP PENCEGAHAN PENULARAN VIRUS COVID19. Jurnal Abdimas Tri Dharma Manajemen, 2(2), 91-98.

Pasaribu, V. L. D., Septiani, F., Rahayu, S., Lismiatun, L., Arief, M., Juanda, A., ... \& Rahim, R. (2021). Forecast Analysis of Gross Regional Domestic Product based on the Linear Regression Algorithm Technique.

Pasaribu, V. L. D., Priadi, A., Anismadiyah, V., Rahayu, S., \& Maduningtias, L. (2021). PENYULUHAN KREATIF DAN INOVATIF MENINGKATKAN MUTU PRODUKSI UMKM DI DESA BELEGA KABUPATEN GIANYAR. Pro Bono Jurnal Pengabdian Kepada Masyarakat, 1(02).

Pasaribu, V. L. D. (2021). PELATIHAN BERBASIS ONLINE DI ERA COVID-19. Jurnal Abdimas Tri Dharma Manajemen, 2(3), 26-32.
Pasaribu, V. L. D., \& Setyowati, R. (2021). ADAPTASI KEHIDUPAN NEW NORMAL PADA MASA PANDEMI COVID-19 DIYAYASAN PONDOK PESANTREN DAN PANTI ASUHAN NURUL IKHSAN KECAMATAN SETU, KOTA TANGERANG SELATAN. Jurnal Lokabmas Kreatif: Loyalitas Kreatifitas Abdi Masyarakat Kreatif, 2(2), 82-88.

Priadi, A., Pasaribu, V. L. D., Virby, S., Sairin, S., \& Wardani, W. G. (2020). Penguatan Ekonomi Kreatif Berbasis Sumber Daya Desa Dikelurahan Rempoa. Abdi Laksana: Jurnal Pengabdian Kepada Masyarakat, 1(3), 356-35

Peraturan Menteri Kesehatan Tentang Perubahan Kedua Atas Peraturan Menteri Kesehatan Nomor 10 Tahun 2021 Tentang Pelaksanaan Vaksinasi Dalam Rangka Penanggulangan Pandemi Corona Virus Disease 2019 (Covid-19).

https://www.suara.com/health/2020/04/13/1 83832/ahli-virus-sebut-covid-19adalah-virus-umum

\section{DOKUMENTASI KEGIATAN}

1. Kegiatan dilakukan Secara tertib dan sesuai dengan protokol kesehatan

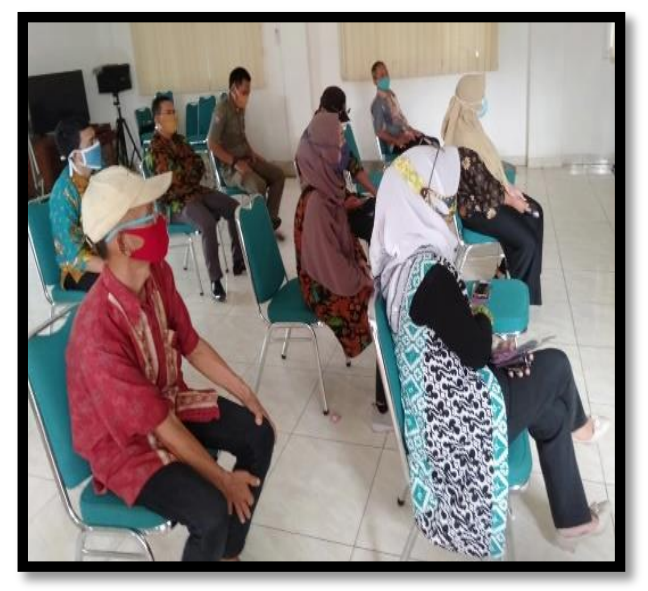


Loyalitas Kreativitas

Aldi Masyarakat Kreatif
P-ISSN 2722-2101, E-ISSN 2722-4201

Program Studi Ekonomi Manajemen Universitas Pamulang

Jurnal LOKABMAS Kreatif Vol.02,No.03.Nov 2021 Hal.31-38

Email:jurnalkreatif.manajemen@gmail.com

5. Foto bersama Dosen Mahasiswa Universitas Pamulang

2.Persiapan materi yang dibawakan oleh Ibu Ayu Puspa Lestiyadi, S.E., M.M
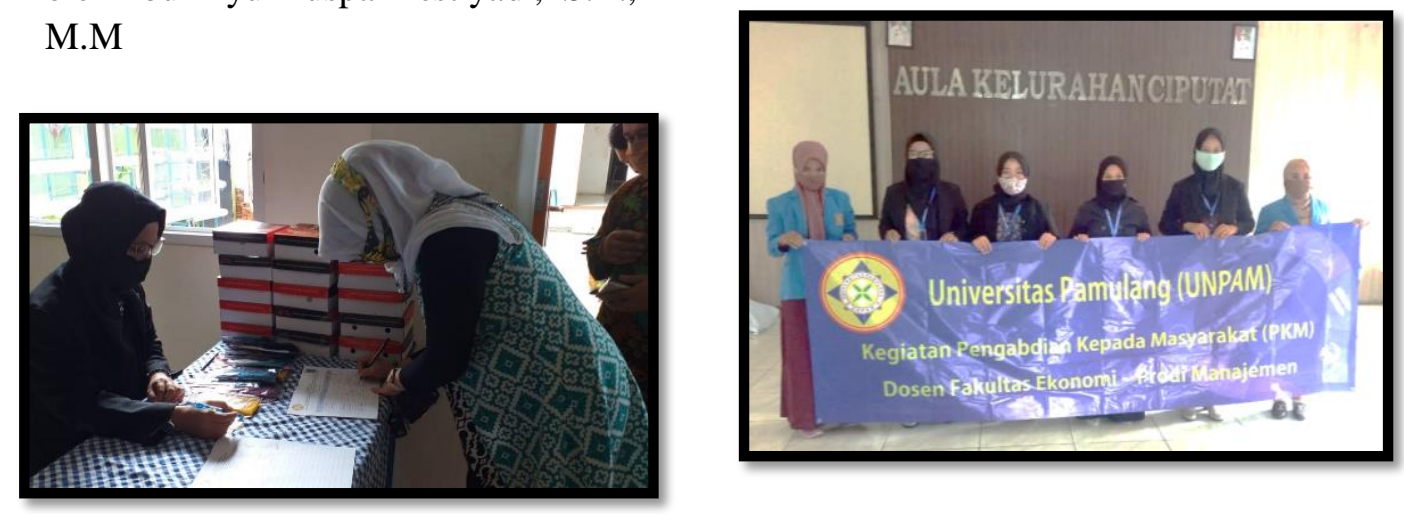

3.Peserta melakukan registrasi secara tertib

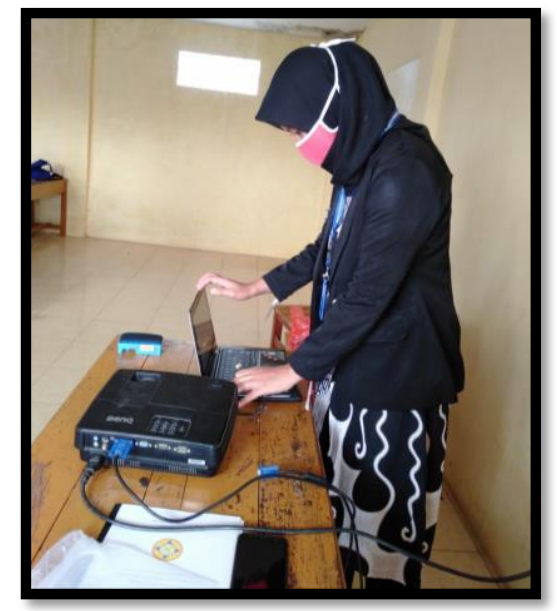

4. Penyerahan souvenir oleh Ketua PKM, Ibu Shella Puspita Sari, S.E., M.M. kepada perwakilan dari staff Kelurahan Ciputat, Tangerang Selatan

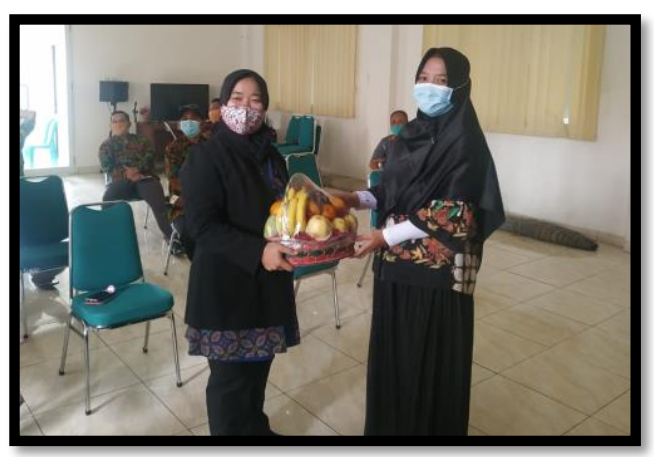

